\title{
Possible Mechanism of Aframomum Sceptrum Extracts Mediated Modulation of Renal Function after Monosodium Glutamate Exposure
}

\author{
Ichipi-Ifukor Patrick Chukwuyenum ${ }^{1 *}$, Ogbeke Geoffrey Ighowho ${ }^{1,2}$, George Betty Omenebelle $^{1}$
}

\begin{abstract}
The objective of the research was to explain the possible mechanism of an earlier reported role of Aframomum sceptrum extract in the modulation of renal function parameters in monosodium glutamate-induced toxicity. Materials and Methods. Similar experimental methods previously reported by us in Ogbeke et al., (2016) were maintained.

Results. Monosodium glutamate administration led to a significant elevation of levels of serum and kidney lipid peroxidation due to decrease in the levels of serum and kidney antioxidant enzyme, super oxide dismutase, catalase, gluthathione peroxidase and gluthathione. There was observed increase in oxidative enzyme, aldehyde oxidase, sulphite oxidase, xanthine oxidase and monoamine oxidase activities in serum and kidney after monosodium glutamate consumption. Aframomum sceptrum treatment significantly regulated all altered indices. Conclusions. The study concluded that the ability of Aframomum sceptrum extract to modulate renal function parameters in monosodium glutamate-induced toxicity is dependent on its efficacy in the induction and mobilization of antioxidant defense armory via the increased synthesis of tissue and serum enzymatic and non-enzymatic antioxidants, as well as improved oxidative enzyme activities that mediates the quenching of rising aldehydes and sulfoxides, $\mathrm{N}$-oxides and aromatic oxides within the kidney.

Keywords

Aframomum sceptrum; oxidative stress; monosodium glutamate; mechanism of kidney function

${ }^{1}$ Department of Biochemistry, Delta State University, Abraka, Delta State, Nigeria

${ }^{2}$ Department of Public Health, Federal Ministry of Health, Abuja, Nigeria

*Corresponding author: patychykyresearch@hotmail.com
\end{abstract}

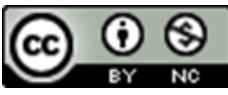

Copyright (C)Ichipi-Ifukor Patrick Chukwuyenum, Ogbeke Geoffrey Ighowho, George Betty Omenebelle, 2019

\section{Problem statement and analysis of the latest research}

Monosodium gluthamate (MSG) is known for its ability to enhance palatability and appetite in diets; however, several indicators suggest that it is toxic to humans and experimental animals [1, 2, 3]. Particularly, there are studies indicating negative outcomes on the hypothalamus-pituitary axis of the brain which have led to neuroexcitatory/neuroendocrine effects and induction of obesity $[4,5,6]$. In ad- dition, earlier and very recent studies have examined other metabolic and toxicological indices and reported the induction of oxidative stress through lipid peroxidation (LPO) in different tissues of experimental animals after administration of chronic doses [7, 8, 9, 10, 11].

Aframomum sceptrum is a well-known spice among southerners in Nigeria. It is popularly called ataiko and is known for its ability to enhance taste and food aroma and improve several alcoholic and non-alcoholic beverages among Urhobos and Uk- 
wuanis of Delta State Nigeria [12, 13]. It has been widely researched and reported to be rich in phytochemicals and possess several ethnopharmocological properties; thus, it is reported for its efficacy in the traditional herbal management of malaria [14], wound healing, management of postnatal malignancies after delivery [15] and the treatment of several models of diabetes mellitus [16, 17]. The efficacy of $A$. sceptrum extracts has been explored in the preservation of food products like meat and the oxidative deterioration of palm oil $[18,19]$. Its efficacy in the prevention of cyanide toxicity in Wistar rats has been reported by Atinaya, D.U et al., [20].

In our earlier report, Ogbeke G.I et al., [21], there was observed a decrease in renal function signified by increased serum urea, creatinine and electrolyte imbalance induced by MSG, while the administration of Aframomum sceptrum contributed to the restoration of these renal malfunctions.

The objective of the research was to explain the possible mechanism of action exerted by Aframomum sceptrum extracts in the modulation of renal malfunction induced by monosodium glutamate toxicity.

\section{Materials and Methods}

The details of the plant collection and extraction, monosodium glutamate purchase and preparation have been published earlier [21]. Thus, experimental design and protocol for animal handling was the same as published by us earlier [21]; the dose of MSG was the same as in the study published by Farombi and Onyema [22] who reported negative effects on selected biochemical parameters. The dose used for the study, therefore, was a single dose of $4 \mathrm{~g} / \mathrm{g}$ body weight of MSG administered intraperitoneally. This paper is a continuation of our research published earlier to explain the possible underlying mechanism for the observations and reports made by us [21].

\subsection{Sample Collection}

At the end of the experimental period, rats were sacrificed via cardiac puncture after which blood and kidney samples collected were prepared as de- scribed in our previous report [21].

\subsection{Biochemical Analysis}

Biochemical analysis was carried out following standard protocols and all reagents used were of analytical grade. Based on this, the assay of level of lipid peroxidation (MDA) was carried out by method of Gutteridge and Wilkins [23] and oxidative enzymes was carried out as follows; Aldehyde oxidase (AO) [24], Sulphite oxidase (SO) [25]; Monoamine Oxidase (MO) and Xanthine oxidase (XO) [26]. Ellman [27] for assay of reduced glutathione (GSH). Assay for specific activities of enzymatic antioxidants was done using the methods of Misra and Fridovich [28] for super oxide dismutase (SOD), Cohen et al. [29] for catalase (CAT), Habig et al. [30] and Khan et al. [31] for glutathione peroxidase (GPx).

\subsection{Statistical Analysis}

Results are presented as means \pm standard deviation and analyzed using the analysis of variance (ANOVA), while comparisons were made using least significant difference (LSD) at $\mathrm{p}<0.05$ level of significance.

\section{Results}

According to Table 1, MSG administration significantly reduced antioxidant enzyme (SOD, CAT, GPx) activities and levels of GSH in the serum and liver, while the administration of both doses of $A$. sceptrum extract increased the activities of serum and kidney SOD and CAT, whereas only $350 \mathrm{mgKg}^{-1}$ increased Gpx activities, and GSH was not reversed.

According to Table 2, all kidney antioxidant activities increased significantly due to the administration of both doses of $A$. sceptrum (groups $\mathrm{C}$ and D) as compared to group B and reduced as compared to group A. The administration of only both doses of A. sceptrum (groups E and F) reduced antioxidant enzyme activities and levels of GSH.

Table 3 and Table 4 show that there were significantly increased MDA levels in the serum and kidney of rats administered only MSG (group B) as 
Table 1. Effect of A. sceptrum extract on serum antioxidant activities.

\begin{tabular}{ccccc}
\hline Groups & $\begin{array}{c}\text { SOD } \\
\left(\text { Unitsml }^{-1}\right)\end{array}$ & $\begin{array}{c}\text { CAT } \\
\left(\mu \text { molmin }^{-1} \mathrm{ml}^{-1}\right)\end{array}$ & $\begin{array}{c}\text { GPx } \\
\left(\mu \mathrm{molml}^{-1}\right)\end{array}$ & $\begin{array}{c}\text { GSH } \\
\left(\mu \mathrm{molml}^{-1}\right)\end{array}$ \\
\hline A $^{*}$ & $44.75 \pm 2.44^{\mathrm{a}}$ & $56.52 \pm 0.85^{\mathrm{a}}$ & $12.08 \pm 1.24^{\mathrm{a}}$ & $14.33 \pm 1.58^{\mathrm{a}}$ \\
$\mathrm{B}$ & $21.72 \pm 1.73^{\mathrm{b}}$ & $29.74 \pm 1.29^{\mathrm{b}}$ & $7.03 \pm 0.91^{\mathrm{b}}$ & $7.08 \pm 0.84^{\mathrm{b}}$ \\
$\mathrm{C}$ & $34.56 \pm 2.33^{\mathrm{c}}$ & $34.65 \pm 1.83^{\mathrm{c}}$ & $6.14 \pm 3.14^{\mathrm{b}}$ & $6.05 \pm 0.96^{\mathrm{c}}$ \\
$\mathrm{D}$ & $35.37 \pm 3.15^{\mathrm{c}}$ & $42.74 \pm 1.59^{\mathrm{d}}$ & $10.08 \pm 2.07^{\mathrm{ab}}$ & $6.50 \pm 1.01^{\mathrm{a}}$ \\
$\mathrm{E}$ & $37.37 \pm 1.15^{\mathrm{c}}$ & $50.19 \pm 2.76^{\mathrm{e}}$ & $9.84 \pm 1.74^{\mathrm{b}}$ & $9.25 \pm 1.81^{\mathrm{a}}$ \\
F & $42.70 \pm 1.67^{\mathrm{ac}}$ & $46.58 \pm 2.00^{\mathrm{d}}$ & $8.03 \pm 1.06^{\mathrm{b}}$ & $8.03 \pm 1.25^{\mathrm{d}}$ \\
\hline
\end{tabular}

Note: Values are given as mean \pm standard deviation; values not sharing a common superscript alphabet letter in the same column differ significantly at $(\mathrm{p}<0.05)$.

- $\mathrm{A}=$ Normal Control;

- $\mathrm{B}=\mathrm{MSG}$ Control;

- $\mathrm{C}=\mathrm{MSG}+250 \mathrm{mg} / \mathrm{Kg}^{-1}$;

- $\mathrm{D}=\mathrm{MSG}+350 \mathrm{mg} / \mathrm{Kg}^{-1}$ A. sceptrum extract;

- $\mathrm{E}=250 \mathrm{mg} / \mathrm{Kg}^{-1}$ A.sceptrum extract;

- $\mathrm{F}=350 \mathrm{mg} / \mathrm{Kg}^{-1}$ A. sceptrum extract

Table 2. Effect of A. sceptrum on kidney antioxidant activities.

\begin{tabular}{|c|c|c|c|c|}
\hline Groups & $\begin{array}{c}\text { SOD } \\
\text { (Unitsg }{ }^{-1} \text { tissue) }\end{array}$ & $\begin{array}{c}\text { CAT } \\
\left(\mu \text { molmin }^{-1} \mathrm{~g}^{-1} \text { protein }\right)\end{array}$ & $\begin{array}{c}\text { GSH } \\
\left(\mu \text { molmg }^{-1} \text { protein }\right)\end{array}$ & $\begin{array}{c}\mathrm{GPx} \\
\left(\mu \mathrm{molmg}^{-1} \text { protein }\right)\end{array}$ \\
\hline $\mathrm{A}^{*}$ & $30.52 \pm 0.85^{\mathrm{a}}$ & $42.15 \pm 6.23^{\mathrm{a}}$ & $11.33 \pm 2.35^{\mathrm{a}}$ & $15.28 \pm 2.14^{\mathrm{a}}$ \\
\hline B & $20.73 \pm 1.05^{b}$ & $18.38 \pm 0.91^{b}$ & $5.51 \pm 0.99^{b}$ & $6.23 \pm 1.08^{b}$ \\
\hline $\mathrm{C}$ & $22.11 \pm 1.81^{\mathrm{a}}$ & $22.20 \pm 9.22^{c}$ & $7.55 \pm 0.69^{c}$ & $7.04 \pm 2.04^{b}$ \\
\hline $\mathrm{D}$ & $23.35 \pm 1.66^{\mathrm{a}}$ & $25.50 \pm 1.83^{\mathrm{d}}$ & $9.50 \pm 1.05^{\mathrm{a}}$ & $12.11 \pm 1.27^{\mathrm{a}}$ \\
\hline $\mathrm{E}$ & $26.47 \pm 0.96^{\mathrm{b}}$ & $30.05 \pm 2.13^{\mathrm{e}}$ & $7.70 \pm 0.80^{\mathrm{a}}$ & $14.48 \pm 1.64^{\mathrm{a}}$ \\
\hline $\mathrm{F}$ & $27.79 \pm 0.86^{\mathrm{a}}$ & $25.50 \pm 1.83^{\mathrm{a}}$ & $5.83 \pm 0.75^{\mathrm{d}}$ & $13.98 \pm 0.96^{\mathrm{a}}$ \\
\hline
\end{tabular}

Note: Values are given as mean \pm standard deviation, $\mathrm{n}=6$; values not sharing a common superscript alphabet letter in the same column differ significantly at $(\mathrm{p}<0.05)$.

Table 3. Effect of A. sceptrum on activities of serum lipid peroxidation and oxidative enzymes.

\begin{tabular}{cccccc}
\hline Groups & $\begin{array}{c}\text { MDA } \\
\left(\mu \text { molml }^{-1}\right)\end{array}$ & $\begin{array}{c}\text { AO } \\
\left(\text { Unitsml }^{-1}\right)\end{array}$ & $\begin{array}{c}\text { SO } \\
\left(\text { Unitsml }^{-1}\right)\end{array}$ & $\begin{array}{c}\text { MO } \\
\left(\text { Unitsml }^{-1}\right)\end{array}$ & $\begin{array}{c}\text { XO } \\
\left(\text { Unitsml }^{-1}\right)\end{array}$ \\
\hline A & $2.14 \pm 0.85^{\mathrm{a}}$ & $4.95 \pm 1.26^{\mathrm{a}}$ & $2.84 \pm 0.85^{\mathrm{a}}$ & $10.71 \pm 1.06^{\mathrm{ac}}$ & $8.32 \pm 0.95^{\mathrm{a}}$ \\
$\mathrm{B}$ & $6.77 \pm 0.64^{\mathrm{b}}$ & $14.22 \pm 0.98^{\mathrm{b}}$ & $8.88 \pm 1.09^{\mathrm{b}}$ & $13.14 \pm 1.52^{\mathrm{b}}$ & $9.84 \pm 1.24^{\mathrm{a}}$ \\
$\mathrm{C}$ & $6.03 \pm 0.87^{\mathrm{b}}$ & $11.20 \pm 0.78^{\mathrm{c}}$ & $10.02 \pm 0.78^{\mathrm{b}}$ & $11.22 \pm 0.78 \mathrm{a}^{\mathrm{b}}$ & $7.40 \pm 0.98^{\mathrm{a}}$ \\
$\mathrm{D}$ & $5.28 \pm 1.59^{\mathrm{bc}}$ & $13.58 \pm 1.88^{\mathrm{c}}$ & $8.04 \pm 0.48^{\mathrm{bc}}$ & $8.09 \pm 1.02^{\mathrm{c}}$ & $7.84 \pm 0.58^{\mathrm{a}}$ \\
E & $3.60 \pm 1.03^{\mathrm{ac}}$ & $8.15 \pm 1.52^{\mathrm{d}}$ & $6.88 \pm 0.96^{\mathrm{cd}}$ & $7.28 \pm 2.67^{\mathrm{c}}$ & $7.56 \pm 0.06^{\mathrm{a}}$ \\
F & $3.55 \pm 0.67^{\mathrm{ac}}$ & $7.63 \pm 1.80^{\mathrm{d}}$ & $4.86 \pm 0.18^{\mathrm{s}}$ & $12.04 \pm 2.05^{\mathrm{ab}}$ & $9.01 \pm 1.40^{\mathrm{a}}$
\end{tabular}

Note: Values are given as mean \pm standard deviation, $\mathrm{n}=6$; values not sharing a common superscript alphabet letter in the same column differ significantly at $(\mathrm{p}<0.05)$. 
Table 4. Effect of A. sceptrum on renal oxidative enzyme activities.

\begin{tabular}{cccccc}
\hline Groups & $\begin{array}{c}\text { MDA } \\
\left(\mu \text { molml }^{-1}\right)\end{array}$ & $\begin{array}{c}\text { AO } \\
\left(\text { Unitsg }^{-1} \text { tissue }\right)\end{array}$ & $\begin{array}{c}\text { SO } \\
\left(\text { Unitsg }^{-1} \text { tissue }\right)\end{array}$ & $\begin{array}{c}\text { MO } \\
\left.\left(\text { Units }^{-1} \text { tissue }\right)^{\mathrm{a}}\right)\end{array}$ & $\begin{array}{c}\text { XO } \\
\left(\text { Unitsg }^{-1} \text { tissue }\right)\end{array}$ \\
\hline A & $2.22 \pm 1.01^{\mathrm{a}}$ & $3.92 \pm 0.68^{\mathrm{a}}$ & $1.88 \pm 0.03^{\mathrm{a}}$ & $12.18 \pm 2.66^{\mathrm{a}}$ & $10.73 \pm 1.15^{\mathrm{a}}$ \\
$\mathrm{B}$ & $6.44 \pm 1.10^{\mathrm{b}}$ & $15.72 \pm 1.44^{\mathrm{b}}$ & $10.78 \pm 1.17^{\mathrm{b}}$ & $22.08 \pm 2.25^{\mathrm{b}}$ & $18.14 \pm 2.42^{\mathrm{b}}$ \\
$\mathrm{C}$ & $5.97 \pm 0.76^{\mathrm{b}}$ & $12.08 \pm 1.18^{\mathrm{bc}}$ & $9.40 \pm 2.34^{\mathrm{bc}}$ & $17.58 \pm 2.56^{\mathrm{c}}$ & $11.24 \pm 1.14^{\mathrm{a}}$ \\
$\mathrm{D}$ & $5.59 \pm 0.93^{\mathrm{b}}$ & $11.78 \pm 3.22^{\mathrm{bc}}$ & $7.24 \pm 1.11^{\mathrm{c}}$ & $16.92 \pm 1.22^{\mathrm{ac}}$ & $12.46 \pm 0.98^{\mathrm{a}}$ \\
$\mathrm{E}$ & $3.55 \pm 0.78^{\mathrm{c}}$ & $9.74 \pm 2.06^{\mathrm{c}}$ & $8.32 \pm 2.08^{\mathrm{bc}}$ & $14.18 \pm 1.98^{\mathrm{ac}}$ & $8.72 \pm 1.18^{\mathrm{c}}$ \\
F & $3.95 \pm 1.02^{\mathrm{c}}$ & $9.88 \pm 2.37^{\mathrm{c}}$ & $7.94 \pm 1.05^{\mathrm{c}}$ & $13.64 \pm 2.05^{\mathrm{ac}}$ & $9.41 \pm 3.4^{\mathrm{c}}$ \\
\hline
\end{tabular}

Note: Values are given as mean \pm standard deviation, $\mathrm{n}=6$; values not sharing a common superscript alphabet letter in the same column differ significantly at $(\mathrm{p}<0.05)$.

compared to the control group. However, the administration of both doses of A. sceptrum (groups $\mathrm{C}$ and D) did not significantly reverse rising MDA. Only A. sceptrum treatment (groups E and $\mathrm{F}$ ) did not increase MDA levels significantly. Oxidative enzymes (AO, SO, MO) were observed to increase in the serum and kidney of rats treated with MSG only (group B) as compared to the control group; serum $\mathrm{XO}$ activities remained significantly unaltered across all groups. Kidney XO significantly increased only in group B and reduced in groups $\mathrm{E}$ and $\mathrm{F}$ as compared to the control group. Serum AO and SO of rats in Group C reduced significantly as compared to group $\mathrm{B}$, while kidney $\mathrm{AO}$ and SO did not reduce significantly. Treatment with $A$. sceptrum extracts reversed increasing trend of serum and kidney $\mathrm{AO}$ in groups $\mathrm{D}-\mathrm{F}$ except for group D AO which was not significant as compared to group B in the kidney. MSG elevated serum and renal $\mathrm{MO}$ activities in group $\mathrm{B}$ as compared to the control group, while the administration of A. sceptrum significantly reduced this trend in other groups close to control values.

\section{Discussion}

Perturbations in enzyme activities responsible for systemic defense are established biomarkers of normal responses to the management of negative outcomes due to toxins $[32,33,34,35]$. The observed decrease in serum and renal antioxidant enzymes (Tables 1, 2) in group B might be a result of compromise of tissue defense against the pernicious out- comes mediated by MSG administration. In our earlier report [21], we hypothesized that the decrease in serum creatinine/urea clearance might be a result of glomerular filtration functionality loss that led to the increase in generation capacities of oxidative stressors. This hypothesis was thus given a level of confirmatory insight owing to the increase in MDA in serum/kidney. Increased LPO is an established attribute for noxiousness and boost in ROS, RNS, superoxide anion $\left(\mathrm{O}_{2}^{-}\right)$hydroxyls $\left(\mathrm{OH}^{-}\right)$and peroxides synthesis capable of compromising tissue architecture [35, 36, 37, 38, 39, 40]. Similarly, the findings in this study are in agreement with earlier studies that were obtained in MDA which gave rise to increased $\mathrm{AO}, \mathrm{SO}, \mathrm{MO}$ and $\mathrm{XO}$ enzyme activities and this could also result from their activation by beneficial components inherent in plant extracts $[12,41]$.

The ability of $A$. sceptrum extracts to contribute to amplification of antioxidant enzyme activities, a decrease in LPO and oxidative enzymes activities confirms our previous statement [21] about its ability to protect the kidney against MSG-induced oxidative organ deterioration and loss of functional capabilities. This action could become possible due to the high content of phytochemicals such as polyphenols, flavonoids and catechins which were previously used to induce defense against toxic substances. Therefore, it is important to state that the possible mechanism used by MSG to exert its threatening effects on renal function is the constant release of reactive radicals, depletion of antioxidants, 


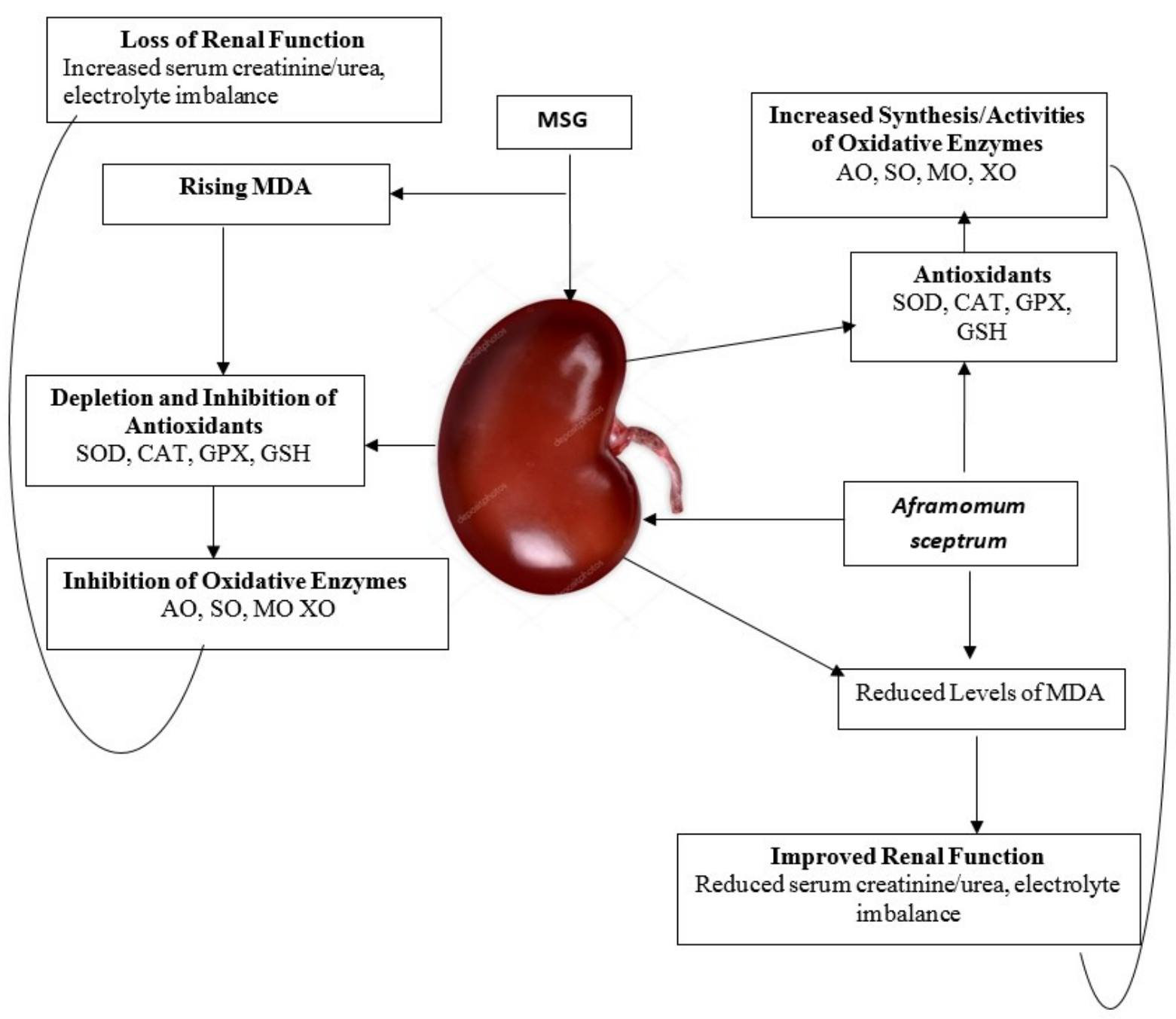

Figure 1. Proposed possible mechanism of Aframomum sceptrum modulation of renal function in MSG-induced toxicity.

concurrent inhibition of oxidative enzymes (AO, $\mathrm{SO}, \mathrm{MO}, \mathrm{XO}$ ) which further mediates the gradual loss of kidney architecture (Fig. 1) leading to its inability to successfully filter urea/creatinine in serum, loss of electrolytes and maintenance of proper acidbase balance under normal body functioning as we reported earlier [21]. Similarly, another possible mechanism for the intervention of A. sceptrum extract may be due to its ability to influence positively increased synthesis of several component antioxidants against several trespassing toxicants capable of promoting MDA generation (Fig. 1). This is consistent with similar reports of the ability of some plant materials (Piper longum Linn and
Moringa oleifera) to mitigate renal and hepatic malfunction induced by MSG [42, 43].

\section{Conclusions}

Based on the evidence mentioned above, it is concluded that the ability of Aframomum sceptrum extract to modulate renal function parameters in MSGinduced toxicity is dependent on its efficacy in the induction and mobilization of antioxidant defense armory via the increased synthesis of tissue and serum antioxidant and non-antioxidant enzymes, as well as improved oxidative enzyme activities that contributes to the quenching of the negative effects of rising MDA levels within the kidney. 


\section{Declaration}

The authors declare that there is no conflict of interest and that there was no external source of funding or sponsorship for this study.

\section{References}

[1] Sharma A. Monosodium glutamate-induced oxidative kidney damage and possible mechanisms: a mini-review. Journal of Biomedical Science. 2015;22:93. DOI: https : / / doi. org/10.1186/s12929-015-0192-5 [PMid:26493866 PMCid:PMC4618747]

[2] Sharma A, Prasongwattana V, Cha' on U et al. Monosodium glutamate (MSG) consumption is associated with urolithiasis and urinary tract obstruction in rats. PLoS One. 2013;8(9):e75546. DOI: https://doi.org/10. 1371 / journal . pone.0075546

[PMid:24086562 PMCid:PMC3784461]

[3] Sharma A, Wongkham C, Prasongwattana $\mathrm{V}$ et al. Proteomic analysis of kidney in rats chronically exposed to monosodium glutamate. PLoS One. 2014;9(12):e116233. DOI: https://doi.org/10. 1371 / journal.pone.0116233

[PMid:25551610 PMCid:PMC4281147]

[4] Hee J, Hyang-Do H, Hyung Y et al. Chronic Administration of Monosodium Glutamate under Chronic variable Stress Impaired Hypothalamic-Pituitary-Adrenal Axis Function in Rats. Korean $\mathrm{J}$ Physiol Pharmacol. 2010;14(4):213-221. DOI: https://doi. org/10.4196/k jpp.2010.14.4.213 [PMid:20827335 PMCid:PMC2933437]

[5] Marcincakova HV, Ostatníková, D. Monosodium Glutamate Toxic Effects and Their Implications for $\mathrm{Hu}$ man Intake: A Review. JMED Research. 2013;51-71. DOI: https: //doi.org/10.5171/2013.608765

[6] Zehra K, Iffat F, Shaghufta $\mathrm{P}$ et al. Monosodium glutamate: Review on clinical reports, International Journal of Food Properties. 2017;20(2):1807-1815. DOI: https://doi.org/10.1080/ 10942912.2017 .1295260

[7] Singh P, Mann K, Mangat H, Kaur G. Prolonged glutamate excitotoxicity: effects on mitochondrial antioxidants and antioxidant enzymes. Mol Cell Biochem. 2003;243(1-2):139145. DOI: https: / / doi .org/10.1023/ A: 1021668314070 [PMid:12619899]

[8] Diniz YS, Fernandes AA, Campos KE et al. Toxicity of hypercaloric diet and monosodium glutamate: oxidative stress and metabolic shifting in hepatic tissue. Food Chem Toxicol. 2004;42(2):313-319. DOI: https://doi. org/10.1016/j.fct.2003.09.006 [PMid:14667476]

[9] Farombi EO, Onyema OO. Monosodium glutamate-induced oxidative damage and genotoxicity in the rat: modulatory role of vitamin $\mathrm{C}$, vitamin $\mathrm{E}$ and quercetin. Hum Exp Toxicol. 2006;25(5):251-259. DOI: https://doi. org/10.1191/0960327106ht621oa [PMid:16758767]

[10] Calis IU, Cosan DT, Saydam F et al. The effects of monosodium glutamate and tannic acid on adult rats. Iran Red Crescent Med J. 2016;18(10):e37912. DOI: https: //doi.org/10.5812/ircmj.37912

[PMid:28184327 PMCid:PMC5291937]

[11] Eman AE, Merhan MR, Sabreen MA. Evidence of the protective effect of 1-arginine and vitamin D against monosodium glutamateinduced liver and kidney dysfunction in rats. Biomed Pharmacother. 2018;108:799-808. DOI: https://doi.org/10.1016/j. biopha. 2018.09 .093 [PMid:30253372]

[12] Ndukwu BC, Ben-Nwadibia. Ethnomedicinal aspects of plants used as spices andcondiments in Niger Delta area of Nigeria. Ethnonobotanicals Leaflets. 2005;10:10. 
[13] Erukainure OL, Oke OV, Owolabi FO et al. Chemical composition and antioxidant activities of Aframomum sceptrum. Trends in Applied Science Research. 2011;6(2):190197. DOI: https://doi.org/10.3923/ tasr.2011.190.197

[14] Anigboro AA. Antioxidant effect of aqueous seed extract of Aframomum sceptrum (Kschum) on brain and kidney of malaria infested mice. Nigerian Journal of Science and Environment. 2016;14(1):102-106.

[15] Feitosa EA, Haroudo Satiro Xavier HS, Randau KP. Chrysobalanaceae: traditional uses, phytochemistry and pharmacology. Revista Brasileira de Farmacognosia. 2012;(22):514. DOI: https://doi.org/10.1590/ s0102-695X2012005000080

[16] George BO, Osioma E, Falodun A. Effect of Atiko (Aframomum sceptrum) and African nutmeg (Monodora myristica) on reduced glutathione, uric acid levels and liver marker enzymes in streptozotocininduced diabetic rats. Egyptian Journal of Biochemistry and Molecular Biology. 2010;28(2). DOI: https://doi .org/10. $4314 /$ ejbmb.v28i2.60794

[17] Dokubo A, Uwakwe AA, Amadi BA. Effects of Aframomum Sceptrum and Parinari Congensis Seed Extracts in Alloxan Induced-Diabetic Wistar Albino Rats. International Journal of Agriculture and Earth Science. 2017;3(5):2033.

[18] Aguda OY, Bankole SO, Adekunle EA et al. Antifungal and Preservative Effect of Different Species of Aframomum (K. Schum) on Fungi Isolated from Raw Meat and Fish. Journal of Advances in Biology \& Biotechnology. 2019;22(4):1-7. DOI: https : / / doi .org/ 10.9734 / jabb/2019/v22i 430119

[19] Nwankwo PO. Extraction, fractionation and assessment of antioxidant activities of active components of Aframomum sceptrum seeds.
African Journal of Biochemistry Research. 2015;9(10):117-123. DOI: https://doi . org/10.5897/AJBR2015.0846

[20] Atinaya DU, Ichipi-Ifukor PC, George BO et al. Cyanide-induced metabolic stress - the role of Aframomum sceptrum aqueous extract (ASAE). Sokoto Journal of Medical Laboratory Science. 2019;4(3):108-119.

[21] Ogbeke GI, George BO, Ichipi-Ifukor PC. Aframomum Sceptrum Modulation of Renal Function in Monosodium Glutamate (MSG) Induced Toxicity. UK Journal of Pharmaceutical and Bioscience. 2016;4(4)5460. DOI: https://doi .org/10.1016/ j.ijvsm.2018.07.002 [PMid:30564592 PMCid:PMC6286397]

[22] Farombi EO, Onyema O. Monosodium Glutamate-Induced Oxidative Damage and Genotoxicity in the Rat: Modulatory Role of Vitamin C, Vitamin E and Quercetin. Hum Exp Toxicol. 2006;25(5):251-259. DOI: https://doi.org/10.1191/ 0960327106 ht 621oa [PMid:16758767]

[23] Gutteridge JMC, Wilkins C. Copper dependent hydroxyl radical damage to ascorbic acid. Formation of a thiobarbiturie acid reactive products. FEBS Letters. 1982;137:327340. DOI: https://doi .org/10.1016/ $0014-5793$ (82) $80377-3$

[24] Omarov RT, Sagi M, Lips SH. Regulation of aldehyde oxidase and nitrate reductase in roots of barley (Hordeum vulgare L.) by nitrogen source and salinity. J Exper Biol. 1998;49:897902. DOI: https://doi .org/10.1093/ jexbot/49.322.897

[25] Macleod RM, Farkas W, Fridovich I et al. Purification and properties of hepatic sulphite oxidase. J Biol Chem. 1961;236:1841-1846

[26] McEwen CM. Monoamine oxidase (human serum or plasma). Colowick SP, Kaplan NO, editors. Methods in Enzymology. 
New York: Academic Press; c1971. 692693. DOI: https://doi.org/10.1016/ $0076-6879(71) 17120-0$

[27] Ellman GC. Tissue sulflydryl groups. Arch Biochem Biophys. 1959;82:70-77. DOI: https://doi.org/10.1016/ $0003-9861(59) 90090-6$

[28] Misra HP, Fridovich I. The role of superoxide anion in the autooxidation of epinephrine and a sample assay for superoxide dismutase. J Biol Chem. 1972;247:3170-3175

[29] Cohen HJ, Betcher-Lange, Kessler DL et al. Hepatic sulphite oxidase congruency in mitochondria of prosthetic groups and activity. J Biol Chem. 1972;247(2):7759-7766.

[30] Habig WH, Pabst MJ, Jakoby WB. Glutathione -s-transferases: first enzymic step in mercapturic acid formation. J Biol Chem. 1974;249:7130-7139.

[31] Khan MR, Rizvi W, Khan RA, Sheen S. Carbon tetrachloride induced nephrotoxicity in rats: protective role of Digera muricata. J Ethnopharmacol. 2009;122:9199. DOI: https://doi.org/10.1016/ j.jep.2008.12.006 [PMid:19118616]

[32] Asagba SO. Alteration in the activity of oxidative enzymes in the tissues of male Wistar Albino rats exposed to cadmium. Int $\mathbf{J}$ Occup Med Environ Health. 2010;23(1):5562. DOI: https://doi.org/10.2478/ v10001-010-0002-y [PMid:20442063]

[33] Achuba FI. Modulation of crude oil induced alteration of oxidative stress indices in rat by red palm oil. J Appl Sci Environ Mgt. 2018;22(6):929-932. DOI: https://doi. org/10.4314/jasem.v22i6.15

[34] Achuba FI. Bitter leaf (Vernonia amygdalina Del) extract potentiates testicular metabolic stress induced by petroleum-tainted diets in rats. Nigerian Journal of Pharmaceutical and Applied Science Research. 2019;8(1):44-51.
[35] Kadiri HE, Asagba SO. The chronic effects of cyanide on oxidative indices in the domestic chicken. Journal of Basic and Applied Zoology. 2019;80(30). DOI: https : / / doi . org/10.1186/s41936-019-0098-y

[36] Achuba FI. Role of bitter leaf (Vernonia amygdalina) extract in prevention of renal toxicity induced by crude petroleum contaminated diets in rats. Int J Vet Sci Med. 2018; 6(2):172177. DOI: https://doi.org/10.1016/ j.ijvsm.2018.07.002 [PMid:30564592 PMCid:PMC6286397]

[37] Asagba SO. Cadmium in our food and drinking water - should we be worried? 70th in the series of inaugural lectures of the Delta State University, Abraka. 2019;14th February, Delsu Press.

[38] Asagba SO, Eriyamremu GE. Oral cadmium exposure and haematological and liver function parameters of rats fed a Nigerian-like diet. J Nutr Environ Med. 2007;16(3-4):267274. DOI: https://doi .org/10.1080/ 13590840701775403

[39] Kweki GR, Ichipi-Ifukor PC, Asagba SO. High Caffeine-Containing Energy Drink-Induced Metabolic Stress in Rats. Sok J Med Lab Sci. 2018;3(3):86-93.

[40] Ezedom T, Asagba SO. Effect of a controlled food-chain mediated exposure to cadmium and arsenic on oxidative enzymes in the tissues of rats. Toxicol Rep. 2016;3:708-715. DOI: https://doi.org/10.1016/j. toxrep.2016.07.002 [PMid:28959596 PMCid:PMC5615934]

[41] Ichipi-Ifukor PC, Asagba SO, Kweki GR et al. Attenuation of Oxidative Enzymes Induction in Palm Oil Fractions Pre-treated Cadmium Intoxicated Rats. Trop J Nat Prod Res. 2019;3(4):107-112. DOI: https:// doi.org/10.26538/tjnpr/v3i4.2

[42] Thomas M., Sujatha KS, George S. Protective effect of Piper longum Linn. on monosodium 
glutamate induced oxidative stress in rats. Indian J Exp Biol. 2009;47(3):186-192.

[43] Tarfa A, Manal AB. Roles of Moringa oleifera Leaf Extract in Improving the Impact of High Dietary Intake of Monosodium GlutamateInduced Liver Toxicity, Oxidative Stress, Genotoxicity, DNA Damage, and PCNA Alterations in Male Rats. Oxidative Medicine and Cellular Longevity. 2018;4501097. DOI: https: //doi.org/10.1155/2018/4501097 [PMid:30647808 PMCid:PMC6311796]

Received: 2019-10-30

Revised: 2019-11-18

Accepted: 2019-11-20 